\title{
The Effect of Nutmeg Seed (M. fragrans) Extracts Induces Apoptosis in Melanoma Maligna Cell's (B16-F10)
}

\author{
Susianti ${ }^{1,2}$, Ronny Lesmana ${ }^{2,3 *}$, Supriatno Salam ${ }^{1,2}$, Euis Julaeha ${ }^{1}$, Yuni Susanti Pratiwi ${ }^{2,3}$, \\ Nova Sylviana ${ }^{2,3}$, Hanna Goenawan ${ }^{2,3}$, Ahmad Kurniawan $^{4}$, Unang Supratman ${ }^{1,2}$ \\ ${ }^{1}$ Departement of Chemistry, Faculty of Mathematics and Natural Sciences, Universitas Padjadjaran, Jl. Raya Bandung-Sumedang Km 21, \\ Jatinangor 45363, Indonesia \\ ${ }^{2}$ Central Laboratory, Universitas Padjadjaran, Jl. Raya Bandung-Sumedang Km 21, Jatinangor 45363, Indonesia \\ ${ }^{3}$ Physiology Division, Department of Biomedical Sciences, Faculty of Medicine, Universitas Padjadjaran, Jl. Raya Bandung-Sumedang Km 21, \\ Jatinangor 45363, Indonesia \\ ${ }^{4}$ Center for Applied Nuclear Science and Technology, National Nuclear Energy Agency (BATAN), Jl. Tamansari No.71, Bandung 40132, Indonesia \\ *Corresponding author. E-mail: ronny@unpad.ac.id
}

Received date: Oct 17, 2020; Revised date: Jan 4, 2021; Accepted date: Jan 6, 2021

\section{Abstract}

$\mathrm{B}$ ACKGROUND: Nutmeg (Myristica fragrans $\mathrm{H}$.), one of native plants of Maluku Indonesia, has long been used as traditional medicines especially to treat tumors, externally to treat skin infections. $M$. fragrans also has important biological activities as anticancer. However, antimelanoma activity of $M$. fragrans remains unknown. The aim of this study is to compare $M$. fragrans extracts as anticancer on melanoma B16-F10 cells by inducing apoptosis.

METHODS: $M$. fragrans seed was extracted with ethanol then fractionated with n-hexane, ethyl acetate, and n-butanol. B16-F10 melanoma cells were cultured and treated with various doses and tested using resazurin reduction assay. Apoptosis signalling via caspase-3 was measured by using western blot.

\section{Introduction}

Melanoma is a type of skin cancer that starts from abnormal proliferation of melanocyte cells as a melanin producer.(1) This cancer has a high level of malignancy and is dangerous to the point of causing death. $(2,3)$ Melanoma cancer cases worldwide reach $>100.000$ cases each year and as many as 66,000 are fatal.(4,5) Lifestyle and genetic factors are risk factors that contribute to the development of melanoma. (6) Exposure to ultraviolet (UV) radiation is the main
RESULTS: The extract and fractions of $M$. fragrans reduced viability of cells with $\mathrm{IC}_{50}$ value for ethanol extract $21.83 \mu \mathrm{g} / \mathrm{mL}$, ethyl acetate fraction $21.66 \mu \mathrm{g} / \mathrm{mL}$, $\mathrm{n}$-hexane fraction $47.53 \mu \mathrm{g} / \mathrm{mL}$, and n-butanol fraction $>1,000 \mu \mathrm{g} /$ $\mathrm{mL}$. The active fraction of ethyl acetate induced apoptosis via caspase-3 proteins similar with cisplatin as positive control in B16-F10 cells at 10 hours treatment.

CONCLUSION: Taken together, $M$. fragrans ethyl acetate fraction has the highest $\mathrm{IC}_{50}$ than $\mathrm{n}$-hexane and n-butanol fractions that significantly inhibited B16-F10 cell proliferation by inducing apoptosis via caspase-3. It provides the insight that it has the most potential activity as a chemopreventive agent for addressing melanoma skin cancer.

KEYWORDS: M. fragrans, apoptosis, fraction, melanoma Indones Biomed J. 2021; 13(1): 68-74 risk factor for melanoma cancer which can cause genetic changes in melanocytes and ultimately damage the DNA of skin cells, damage genes that regulate cell growth and division, resulting in the formation of malignant cells.(7)

Several melanoma therapy methods have been performed, such as surgical operations, chemotherapy, and radiotherapy.(8) Those treatment approaches had not only given side effects like skin damage, also caused a decrease in the effectiveness of radiation along with the number of cancer cells, and can even lead to drug resistance to chemotherapy.(9) Thus, it is necessary to develop 
alternative medicine as a chemopreventive agent, one of which is derived from natural ingredients which have the activities to inhibit the abnormal growth of melanoma cells, and have lower side effects and are safer in their use.

Natural ingredients, especially herbal plants, is generally available in tropical countries, especially in Indonesia. Herbal compounds such as Curcumin, Demethoxycurcumin and Bisdemethoxycurcumin have cytotoxic activity against MCF7 breast cancer cells.(10) Nutmeg (Myristica fragrans $\mathrm{H}$.) is one of the native plants of the Maluku Islands, Indonesia with high economic value with the largest production level of up to $80 \%$ to supply the world's nutmeg as spices.(11,12) As herbal medicinal product, $M$. fragrans has long been used as medicines for digestive problems, such as flatulence and diarrhea. Interestingly, $M$. fragrans can be used to treat tumors, externally to treat skin infections.(13) M. fragrans has important biological activities, such as anticancer (13$15)$ in addition also have antioxidants, anti-inflammatory, antibacterial (16), analgesics (17), and antidiabetic (18). However, its effectivity on melanoma cancer is still limited.

Taken together, detail informations about the activity of $M$. fragrans on B16-F10 melanoma cancer cells and its molecular mechanism has not been elucidated, therefore in the present study, we would like to compare M. fragrans extracts as anticancer on melanoma B16-F10 cells by inducing apoptosis.

\section{Methods}

\section{M. fragrans Seed Extraction and Fractionation}

M. fragrans seed samples were obtained from Sarjo Village, Pasangkayu Regency, West Sulawesi Province and were identified at the Celebense Herbarium at Tadulako University, Palu, Central Sulawesi. Dry M. fragrans seed $(4.1 \mathrm{~kg})$ were extracted by maceration method using ethanol redestillation solvent for $8 \times 24$ hours. Filtrate was then concentrated with a rotary evaporator (Cat. No. R100, Buchi, Flawil, Switzerland) at a temperature of $45^{\circ} \mathrm{C}$. Concentrated ethanol extract was fractionated for 24 hours sequentially with redestillation solvents of $n$-hexane, ethyl acetate, and n-butanol. Then the fractions of n-hexane, ethyl acetate, and n-butanol were concentrated to evaporate the solvent using a rotary evaporator at a temperature of $45^{\circ} \mathrm{C}$.

\section{B16-F10 Melanoma Cell}

B16-F10 cell was acquired from American Type Culture Collection (ATCC® CRL-6475 ${ }^{\mathrm{TM}}$, Manassas, Virginia,
USA). The medium used was Dulbecco's Modified Eagle's Medium (DMEM high glucose) (Cat. No. 11965118, Gibco, New York, USA) added with $10 \%$ Fetal Bovine Serum (FBS) (Cat. No. 10082147, Gibco) and 1\% Penicillin-streptomycin (Cat. No. 15140112, Gibco). Cell incubation was conducted at $37^{\circ} \mathrm{C}$ in a $5 \% \mathrm{CO}_{2}$ incubator (Cat. No. $8000 \mathrm{DH}$, Thermo Fisher Scientific, Waltham, Massachusetts, USA).

\section{Antiproliferation Assay}

B16-F10 melanoma cells ( $1.7 \times 10^{4}$ cells/well) were cultured in 96-well microplates (Cat. No. 701001, Nest, Jiangsu, China) for 24 hours. Then, the cells were treated with $M$. fragrans ethanol extract, $\mathrm{n}$-hexane fraction, ethyl acetate fraction and n-butanol fraction (variations in concentrations of 1,$000 ; 500 ; 250 ; 125 ; 62.50 ; 31.25 ; 15.63 ; 7.81 \mu \mathrm{g} /$ $\mathrm{mL}$ ), cisplatin (Cat. No. C2210000, EDQM, Starsbourg, France) $42.97 \mu \mathrm{g} / \mathrm{mL}$ as a positive control, DMSO (Cat. No. 102952, Merck Millipore, Massachusetts, USA) $2 \%$ as a solvent control, DMEM as a media control, and DMEM with untreated cells, incubated for 48 hours. After that, Presto blue reagent (Cat. No. A13261, Thermo Fisher Scientific) was added to each well, incubated for 2 hours, then the absorbance was measured at $570 \mathrm{~nm}$ and reference at $600 \mathrm{~nm}$ by using multimode reader (Cat. No. M200 Pro, Tecan, Männedorf, Switzerland), and their cell viability and $\mathrm{IC}_{50}$ values were calculated.

\section{Western Blot}

B16-F10 melanoma cells (1.0x10 cells/well) were cultured in a 24-well microplate (Cat. No. 702001, Nest) for 24 hours. Then, the cells were treated using an active fraction of ethyl acetate of $M$. fragrans with a concentration variation of $125 ; 62.50 ; 31.25 ; 15.63 \mu \mathrm{g} / \mathrm{mL}$, and cisplatin $42.97 \mu \mathrm{g} / \mathrm{mL}$ as positive control, incubated for 10 hours. The cells were harvested and processed in vitro. Lysis buffer was added as much as $100 \mu \mathrm{L} /$ well. Lysis buffer contains (1:1) RIPA buffer (Cat. No. 89900, Thermo Fisher Scientific) : sample buffer (Cat. No. 84788, Thermo Fisher Scientific), protein inhibitor (Cat. No. S8820, Sigma Aldrich, Wisconsin, USA), and DTT (Cat. No. V3151, Sigma Aldrich). Samples were heated at $96^{\circ} \mathrm{C}$ for 5 minutes and deep freeze for 2-3 minutes was carried out. Ten $\mu \mathrm{L}$ lysate protein was separated with SDS-PAGE (Cat. No. A25977, Thermo Fisher Scientific) for 120 minutes. The gel produced from SDS-PGE was further transferred to the $0.45 \mu \mathrm{m}$ pore size of nitrocellulose membrane (Cat. No. 10600002, GE Healthcare, Illinois, USA) for 30 minutes by using blotting equipments (Cat. No. B1000, Thermo Fisher Scientific). The membrane was washed with Phosphate Buffer Saline Tween-20 0.1\% 
(PBST) (Cat. No. 18912014, Gibco), incubated using a 0.25\% BSA blocking solution (Cat. No. 1.12018, Sigma Aldrich) for 30 minutes. Membrane immunoblotting was carried out using primary antibodies of caspase-3 (Cat. No. \#14220, Cell Signaling, Massachusetts, USA) with a dilution of 1:300, then it was incubated overnight at $4^{\circ} \mathrm{C}$. The membrane was washed $3 \mathrm{x}$ with $0.1 \%$ PBST, incubated using appropriate secondary antibodies (anti-rabbit (Cat. No. C90501-02, Li-Cor, Nebraska, USA) with a 1:10,000 dilution. Proteins in membrane was detected with LICOR Odyssey (CLx Imaging System, Li-Cor, Nebraska, USA). The thickness of the protein band was analyzed using ImageJ (NIH) software from National Institutes of Health (Bethesda, Maryland, USA). Stripping on the membranes was carried out and then it was incubated using Glyceraldehyde-3-Phosphate Dehydrogenase (GAPDH) (Cat. No. AF5718-SP, RnD System, Minnesota, USA) as an internal control.

\section{Results}

\section{M. fragrans Fraction and Extract Yield}

The concentrated ethanol extract obtained from the maceration process was $2.30 \mathrm{~kg}$ from $4.1 \mathrm{~kg}$ dry $M$. fragrans seeds with a yield value of $56.10 \%$. The amount obtained from the fraction of n-hexane was $521.40 \mathrm{~g}$, ethyl acetate at $602.50 \mathrm{~g}$ and n-butanol at $401.80 \mathrm{~g}$. The highest yield was obtained using ethyl acetate extraction solvent with a yield value of $26.20 \%$.

\section{M. fragrans Extract and Fraction Cytotoxicity in B16-F10 Cell}

The results showed after 48 hours of treatment, there was a morphological change that showed cell death in ethanol extract, ethyl acetate fraction and n-hexane fraction, but no morphological change in the n-butanol fraction (Figure 1B). Significant inhibition was showed at concentration of 1,000 ; $500 ; 250 ; 125 ; 62.50$ and $31.25 \mu \mathrm{g} / \mathrm{mL}$ for ethanol extract and ethyl acetate fraction, followed by n-hexane fraction at concentration of 1,$000 ; 500 ; 250 ; 125$ and $62.50 \mu \mathrm{g} / \mathrm{mL}$ (Figure 1). Percentage of cell inhibition was calculated from liner regression equation by comparing with the $2 \%$ DMSO as a solvent control. The ethyl acetate fraction of $\mathrm{M}$. fragrans significantly inhibited B16-F10 cell proliferation with IC50 value of $21.66 \mu \mathrm{g} / \mathrm{mL}$, followed by ethanol extract 21.83 $\mu \mathrm{g} / \mathrm{mL}$ and n-hexane fraction with IC50 value of $47.53 \mu \mathrm{g} /$ $\mathrm{mL}$. n-butanol fraction did not show cytotoxicity against B16-F10 cell with IC50>1,000 $\mu \mathrm{g} / \mathrm{mL}$.
Figure 2 shows the results from the resazurin reduction assay at the one time points (48 hours) post-treatment with the different concentration where there was a significant decrease in cell viability for ethanol extract and ethyl acetate fraction (rows A and C down to $<20 \%$ ), and fraction n-hexane (row D down to $<40 \%$ ) compared to cisplatin as positive control (60-80\% cell viability), whereas n-butanol did not show a decrease in cell viability. The absolute $\mathrm{IC}_{50}$ value analysis used GraphPad Prism 8 software. The results showed that the ethyl acetate fraction $(18.05 \mu \mathrm{g} / \mathrm{mL})$ had the highest $\mathrm{IC}_{50}$ value, followed by ethanol extract $(27.14 \mu \mathrm{g} /$ $\mathrm{mL})$ and $\mathrm{n}$-hexane fraction $(52.67 \mu \mathrm{g} / \mathrm{mL})$. Ethanol extract and ethyl acetate fraction were also tested for their cytotoxic activity against MCF7 (Supplementary Figure 1).

\section{Induction of Apoptosis by Active Fraction of M. fragrans Ethyl Acetate}

The cytotoxic assay results showed potent inhibitory activity of cell proliferation by ethyl acetate fraction of $M$. fragrans against B16-F10 cells. Therefore, the caspaseinducing activity of the fraction was examined in the B16-F10 cells using western blot. The cells were treated using an active fraction of ethyl acetate of $M$. fragrans with a concentration variation of $125 ; 62.50 ; 31.25 ; 15.63 \mu \mathrm{g} /$ $\mathrm{mL}$, and cisplatin $42.97 \mu \mathrm{g} / \mathrm{mL}$ as a positive control. The specific marker for apoptosis used caspase-3 with GAPDH as an internal control.

As shown in Figure 3, expression protein levels of caspase-3 were similar with cisplatin as a positive control in B16-F10 cells at 10 hours, including caspase 3 fragments with $37 \mathrm{kDa}$ and cleaved caspase 3 with $19 \mathrm{kDa}$. These results suggested that the B16-F10 melanoma cancer cell proliferation inhibition by ethyl acetate fraction of $M$. fragrans induced apoptosis via caspase- 3 proteins.

\section{Discussion}

This research focuses on the effect of $M$. fragrans extract and fraction on B16-F10 melanoma cancer cells and its molecular mechanisms through induction of apoptosis. We also had observed that nutmeg extract and fractions reduced significantly cell viability in others cells cancer like MCF7 (Supplementary Figure 1). Our results showed that the ethanol extract, ethyl acetate fraction and n-hexane fraction suppresses the growth of B16-F10 melanoma cancer cells that seen from cell morphology changes when compare with controls (Figure 1). The morphological changes of cancer cells correlated with cellular proliferation.(19) 

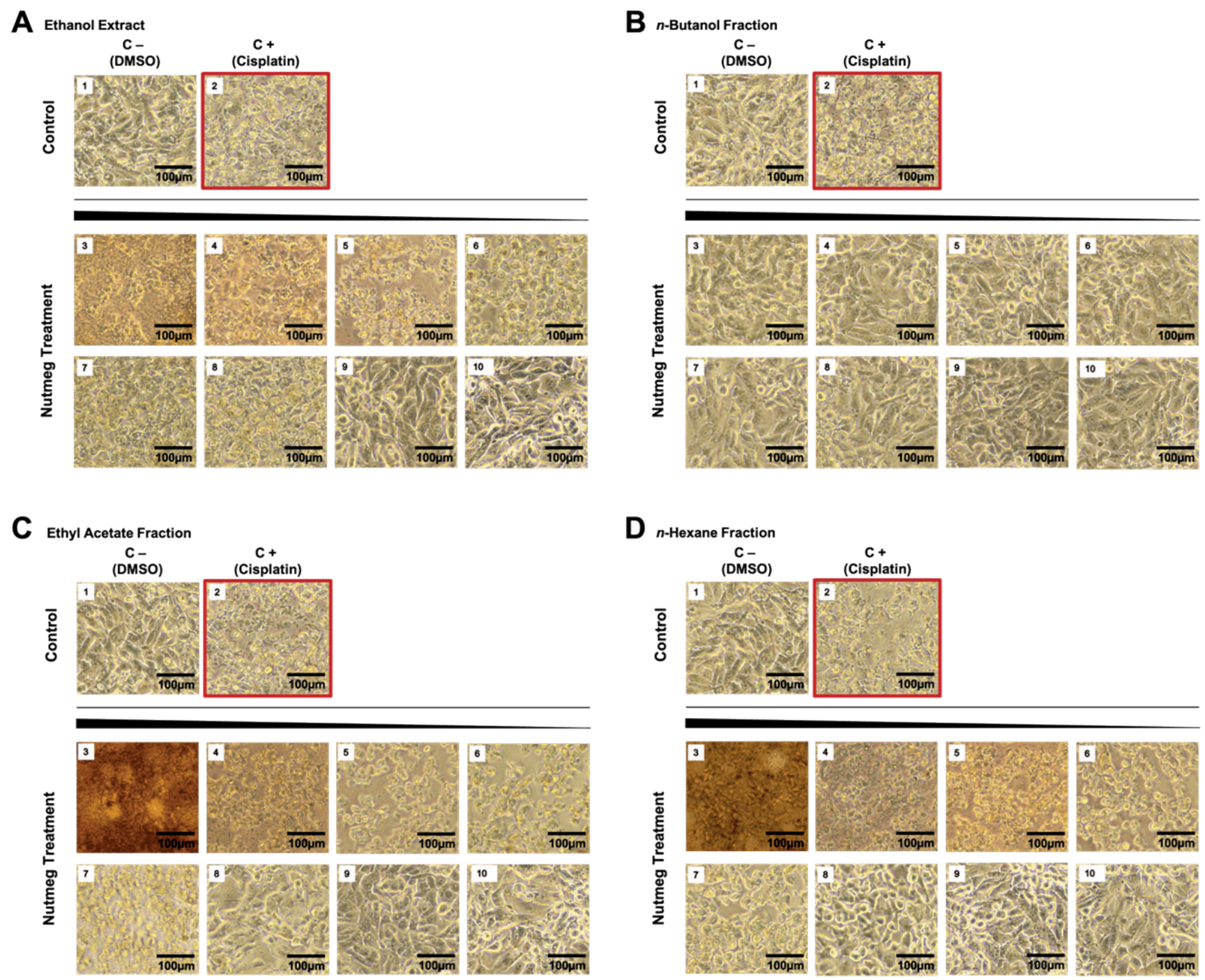

Figure 1. Morphological changes of B16-F10 cells in $M$. fragrans ethanol extract and fraction after antiproliferation assay for 48 hours incubation. 1: solvent control; 2: positive control; 3: concentration of 1,000 $\mu \mathrm{g} / \mathrm{mL}$; 4 : concentration of $500 \mu \mathrm{g} / \mathrm{mL}$; 5 : concentration of $250 \mu \mathrm{g} / \mathrm{mL}$; 6 : concentration of $125 \mu \mathrm{g} / \mathrm{mL} ; 7$ : concentration of $62.50 \mu \mathrm{g} / \mathrm{mL} ; 8$ : concentration of $31.25 \mu \mathrm{g} / \mathrm{mL}$; 9: concentration of 15.63 $\mu \mathrm{g} / \mathrm{mL} ; 10$ : concentration of $7.81 \mu \mathrm{g} / \mathrm{mL}$.

The solvent of each extract has a different polarity so the secondary metabolites contained in the extract appropriate with the solvent polarity.(20) Solvent polarity from polar to non-polar: ethanol > ethyl acetate > n-hexane. Ethyl acetate is a semi-polar solvent that can collect secondary metabolites, both polar and non-polar. From the extraction results, the ethyl acetate fraction has the highest yield value, this indicates that many compounds are collected to the ethyl acetate fraction which have an effect on inhibiting cell proliferation.

The effect of ethyl acetate fraction of $M$. fragrans seeds showed the highest cytotoxic activity, followed by ethanol extract and the n-hexane fraction while the n-butanol fraction did not show cytotoxic activity against B16-F10 melanoma cancer cells. Ethyl acetate fraction could significantly inhibit B16-F10 cell proliferation with $\mathrm{IC}_{50}$ value of $21.66 \mu \mathrm{g} / \mathrm{mL}$ smaller than cisplatin as a positive control. This means that ethyl acetate fraction has higher cytotoxic activity than the cisplatin because at smaller concentrations this fraction has been able to inhibit of $50 \%$ on the growth of B16-F10 melanoma cancer cells.

Cell viability and absolute $\mathrm{IC}_{50}$ (or the theoretically possible effect) analysis were performed.(21) The data showed that the ethyl acetate fraction had significant decrease in cell viability to $>80 \%$ with the highest absolute IC50 value of $18,05 \mu \mathrm{g} / \mathrm{mL}$ (Figure 2), it means ethyl acetate fraction has strong cytotoxic activity of B16-F10 cells. Based on the cytotoxicity classification, the $\mathrm{IC}_{50}$ value is less than $<50 \mu \mathrm{g} / \mathrm{mL}$ has strong cytotoxic activity.(22) 


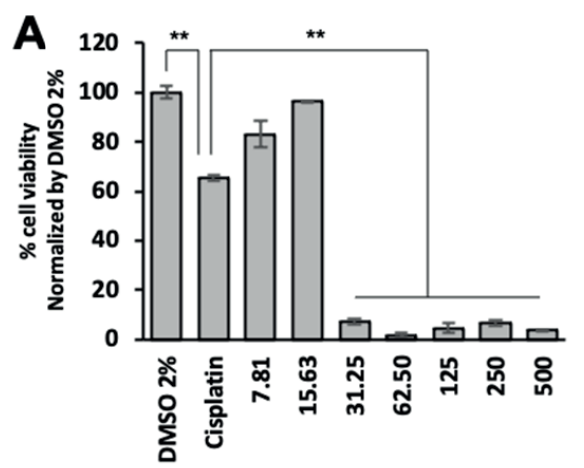

Ethanol Extract $(\mu \mathrm{g} / \mathrm{mL})$
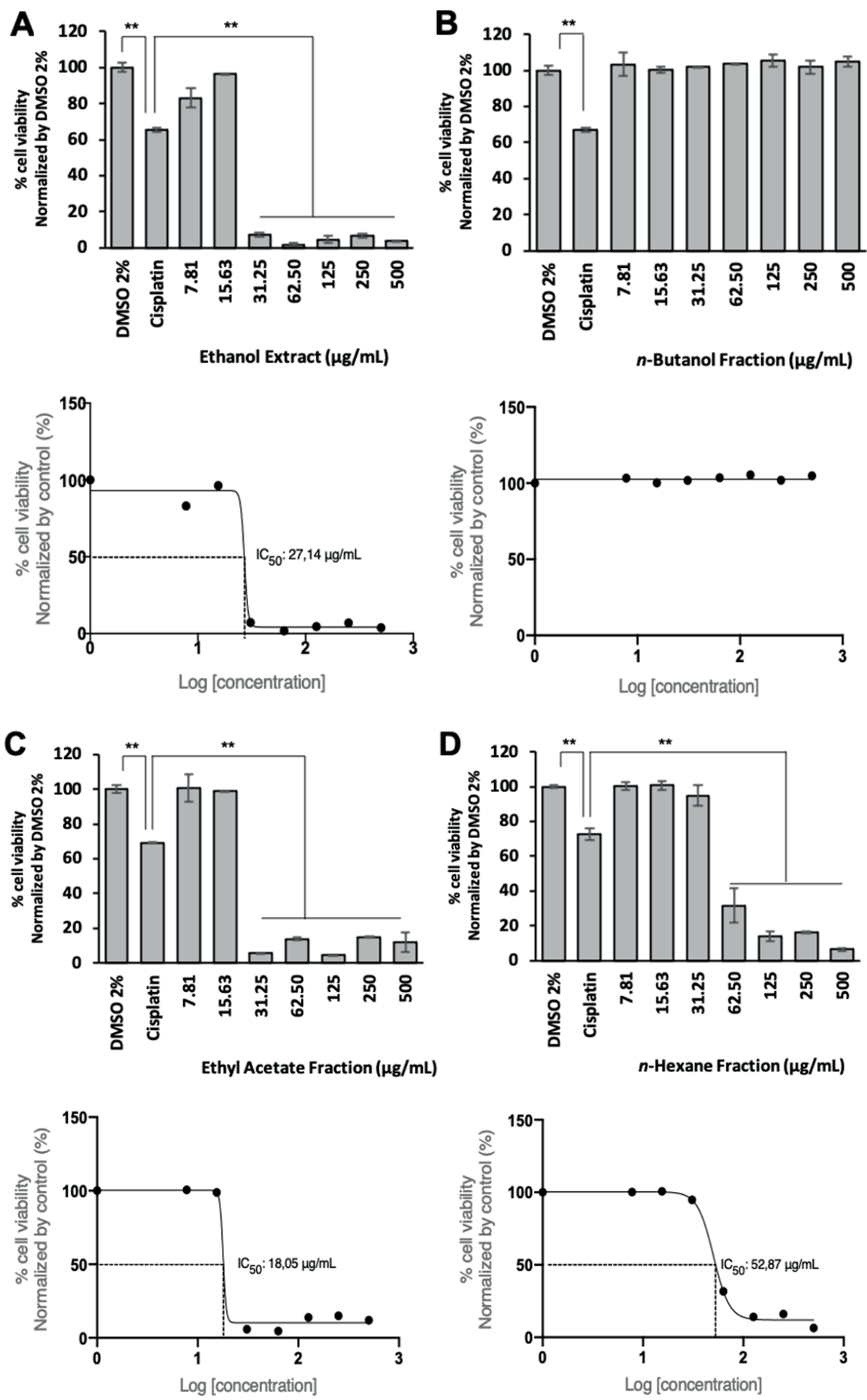

Figure 2. Data of cell viability of $M$. fragrans ethanol extract, n-butanol, ethyl acetate, n-hexane fractions were analyzed and presented as average and standard deviation. **Showed significant difference.
Previous studies reported that ethanol extract of $M$. fragrans with concentration $100 \mu \mathrm{g} / \mathrm{mL}$ can inhibit the growth of 50\% A-549 (Lung) cells using SRB assay.(23) However, there has not been a detailed report regarding the fraction shown to have cytotoxic activity. Our results showed that ethanol extract and ethyl acetate fraction were also tested for their cytotoxic activity against MCF7 (Supplementary Figure 1). These indicate that ethanol extract and ethyl acetate fraction of $M$. fragrans have a promising cytotoxic activity.

Several compounds found in $M$. fragrans ethyl acetate fraction and responsible for cytotoxic activity are lignans, diarylnonanoid and phenylpropanoids.(24-26) Interestingly, we discover an ethyl acetate fraction which has cytotoxic activity. This fact provides the possibility of new active compounds that have the potential to act as 
A



B

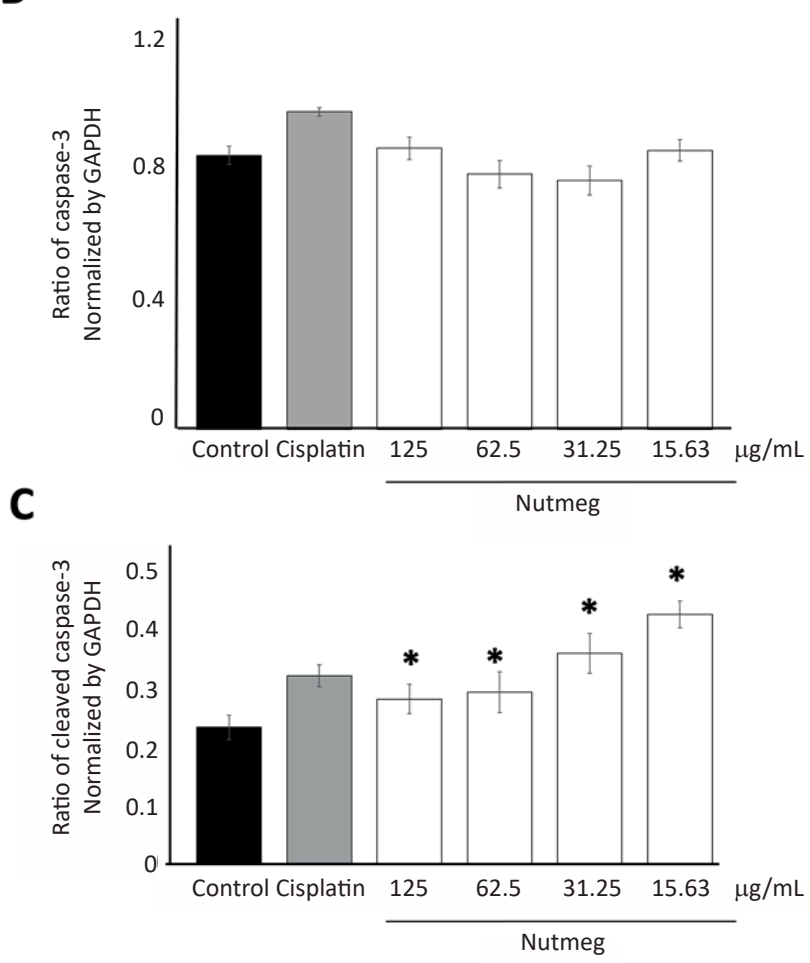

Figure 3. Active fraction of $M$. fragrans ethyl acetate potentially activate caspase- 3 proteins in B16-F10 cells. A: Immunobloting representation of capase-3; B: Ratio total caspase-3 is normalized by GAPDH. C: Ratio cleaved caspase- 3 normalized by GAPDH. Data is presented as mean average with Standard Error Minimum. $* p$-value was significant with $p$-value $<0.05$.

anti-cancer from the ethyl acetate fraction. Also, the effect of nutmeg is widely reported in breast cancer $(24,25,27)$ and other cancers $(25,27-30)$ Using a skin cancer model can provide an alternative use of nutmeg fraction or its active compound as an alternative to skin cancer treatment supplements.

Further research was carried out to find out the molecular mechanism underlying the cytotoxic effect of the active fraction of nutmeg ethyl acetate on B16-F10 cells, one of which was through apoptosis induction. Apoptosis is programmed cell death that can be triggered by endogenous or exogenous signals.(31) Apoptosis has two main signaling pathways, namely extrinsic and intrinsic apoptosis. Most anticancer effects give rise to intrinsic apoptosis pathways. (32-34) One of the apoptosis signaling pathways is caspase through the activation of caspase-3, in which activation of caspase-3 as an effector of the apoptosis process.(35) Licarin A, a lignan from $M$. fragrans cause autophagy dependent apoptosis in NCI-H23 and A549 non-small cell lung cancer cells where autophagy activation was shown by decreased in p62, increased in levels of LC3II and beclin 1, and arrest of G1. For cell death by apoptosis, it was shown by degradation in procaspase 3 , increased in ROS, cleaved PARP, and MMP loss.(28)

Our study shows that $M$. fragrans ethyl acetate fraction can reduce the viability of B16-F10 cells for 10 hours of treatment by inducing B16-F10 cell death through apoptosis via caspase- 3 as indicated by the results of western blot. These results are similar with cisplatin as a positive control (Figure 3). However, further research requires for investigating single $M$. fragrans active compounds that play a role in the process of inhibition of B16-F10 melanoma cells.

The drawback of this research is the limited detailed exploration of others apoptosis upstream and downstream mechanisms like involvement of beclin, PARP, and other potential mechanisms which needs to be explored and investigated.

\section{Conclusion}

M. fragrans ethyl acetate fraction has the highest IC50 than n-hexane and n-butanol fractions that significantly inhibited B16-F10 cell proliferation by inducing apoptosis via caspase-3. It provides the insight that it has the most potential activity as a chemopreventive agent for addressing melanoma skin cancer.

\section{Acknowledgements}

The authors would like to thank Kusmiati Sukmana, Nurul Fadhilah, Canadia Ravelita and Akbar Haqi for technical supports during experiments.

This research was supported by Program Beasiswa PasTi Kemenristekdikti Number: T/64/D3.3/ KD.03.00/2019 to Susianti (2020) and PDUPT DIKTI Research grant Number: 1827/UN6.3.1/LT/2020 to Ronny Lesmana (2020). 


\section{Authors Contribution}

S and SS performed the experiments, analyzed the data and drafted the manuscript. RL and US designed the experiments, supervised the work and wrote the manuscript. EJ, YSP, NS, AK and $\mathrm{HG}$ analyzed the data and drafted the manuscript.

\section{References}

1. Zaidi MR, Fisher DE, Rizos H. Biology of melanocytes and primary melanoma. In: Balch $\mathrm{C}$, Editor. Cutaneous Melanoma. Cham: Springer; 2020. p.3-40.

2. Linares MA, Zakaria A, Nizran P. Skin cancer. Prim Care. 2015; 42: 645-59.

3. Davis EJ, Perez MC, Ayoubi N, Zhao S, Ye F, Wang DY, et al. Clinical correlates of response to Anti-PD-1-based therapy in patients with metastatic melanoma. J Immunother. 2019; 42: 221-7.

4. World Health Organization [Internet]. Radiation: Ultraviolet (UV) radiation and skin cancer. [updated 2017 Oct 16; cited: 2019 April 1]. Available from: https://www.who.int/news-room/q-a-detail/ ultraviolet-(uv)-radiation-and-skin-cancer.

5. Alvarez-Artime A, Cernuda-Cernuda R, Francisco-Artime-Naveda, Cepas V, Gonzalez-Menendez P, Fernadez-Vega S, et al. Melatonininduced cytoskeleton reorganization leads to inhibition of melanoma cancer cell proliferation. Int J Mol Sci. 2020; 21: 548. doi: 10.3390/ ijms 21020548 .

6. Carr S, Smith, C, Wernberg, J. Epidemiology and risk factors of melanoma. Surg Clin North Am. 2020; 100: 1-12. doi: 10.1016/j. suc.2019.09.005.

7. Tracey EH, Vij A. Updates in melanoma. Dermatol Clin. 2019; 37: 73-82.

8. Yu Q, Xie J, Li J, Lu Y, Liao L. Clinical outcomes of BRAF plus MEK inhibition in melanoma: A meta-analysis and systematic review. Cancer Med. 2019; 8: 5414-24.

9. Domingues B, Lopes J, Soares P, Populo H. Melanoma treatment in review. Immunotargets Ther. 2018; 7: 35-49.

10. Lesmana R, Susianti, Pediatama T, Sylviana N, Pratiwi YS, Goenawan $\mathrm{H}$, et al. Active compounds from curcuma longa and comparison of their effectively induced apoptosis in MCF-7 cell. Pak J Biol Sci. 2020; 23: 35-41.

11. Rodianawati I, Hastuti P, Cahyanto MN. Nutmeg's (Myristica fragrans Houtt) oleoresin: effect of heating to chemical compositions and antifungal properties. Procedia Food Sci. 2015; 3: 244-54.

12. Gupta AD, Bansal VK, Babu V, Maithil N. Chemistry, antioxidant and antimicrobial potential of nutmeg (Myristica fragrans Houtt). J Genet Eng Biotechnol. 2013; 11: 25-31.

13. Abourashed EA, El-Alfy AT. Chemical diversity and pharmacological significance of the secondary metabolites of nutmeg (Myristica fragrans Houtt.). Phytochem Rev. 2016; 15: 1035-56.

14. Kuete V. Medicinal spices and vegetables from Africa. 1st ed. Cambridge: Academic Press; 2017.

15. Le TVT, Nguyen PH, Choi HS, Yang JL, Kang KW, Ahn SG, et al. Diarylbutane-type lignans from Myristica fragrans (Nutmeg) show the cytotoxicity against breast cancer cells through activation of AMP-activated protein kinase. Nat Prod Sci. 2017; 23: 21-8.

16. Matulyte I, Jekabsone A, Jankauskaite L, Zavistanaviciute P, Sakiene V, Bartkiene E, et al. The essential oil and hydrolats from Myristica fragrans seeds with magnesium aluminometasilicate as excipient: antioxidant, antibacterial, and anti-inflammatory activity. Foods.
2020; 9: 1-12. doi: 10.3390/foods9010037.

17. Mishra A, Rahman S, Khan R. CNS activity of Myristica fragrans Houtt. - An experimental study. Bangladesh J Med Sci. 2018; 17: 98-106.

18. Lestari K, Diantini A, Barliana MI, Achmad TH, Subarnas A, Mutaki, et al. Potential natural dual agonist PPARa/y-induced antidiabetic and antidyslipidemic properties of safrole-free nutmeg seed (Myristica fragrans Houtt) extract. Nat Prod J. 2019; 9: 248-53.

19. Domura R, Sasaki R, Ishikawa Y, Okamoto M. Cellular morphologymediated proliferation and drug sensitivity of breast cancer cells. J Funct Biomater. 2017; 8: 18. doi: 10.3390/jfb8020018.

20. Chaouki W, Leger DY, Eljastimi J, Beneytout JL, Hmamouchi M. Antiproliferative effect of extracts from Aristolochia baetica and Origanum compactumon human breast cancer cell line MCF-7. Pharm Biol. 2010; 48: 269-274.

21. Nevozhay D. Cheburator software for automatically calculating drug inhibitory concentrations from in vitro screening assays. PloS One. 2014; 9: 1-10. doi: 10.1371/journal.pone.0106186.

22. Dwira S, Ariska TP, Fadilah F, Azizah NN, Erlina L. Comparison of cytotoxicity between ethyl acetate and ethanol extract of white turmeric (Kaempferia rotunda) rhizome extract against HeLa cervical cancer cell activity. Pharmacogn J. 2020; 12: 1297-302.

23. Prakash E, Gupta DK. Cytotoxic activity of ethanolic extract of Myristica fragrans (Houtt) against seven human cancer cell lines. Universal J Food Nutr Sci. 2013; 1: 1-3. doi: 10.13189/ ujfns.2013.010101.

24. Thuong PT, Hung TM, Khoi NM, Nhung HTM, Chinh NT, Quy NT, et al. Cytotoxic and anti-tumor activities of lignans from the seeds of Vietnamese nutmeg Myristica fragrans. Arch Pharm Res. 2014; 37: 399-403.

25. Cuong TD, Lim CJ, Trang TTT, Bae YH, Thu NV, Tung NT, et al. Compounds from the seeds of Myristica fragrans and their cytotoxic activity. Nat Prod Sci. 2012; 18: 97-101.

26. Lee JW, Choi YH, Yoo MY, Choi SU, Hong KS, Lee BH, et al. Inhibitory effect of the seed extract of myristica semen on the proliferation of human tumor cell lines (II). Korean J Pharmacogn. 2006; 37: 206-11.

27. Chumkaew P, Srisawat T. New neolignans from the seeds of Myristica fragrans and their cytotoxic activities. J Nat Med. 2019; 73: 273-77.

28. Maheswari U, Ghosh K, Sadras SR. Licarin A induces cell death by activation of autophagy and apoptosis in non-small cell lung cancer cells. Apoptosis. 2018; 23: 210-25.

29. Min BS, Cuong TD, Hung TM, Min BK, Shin BS, Me HW. Inhibitory effect of lignans from myristica fragrans on LPS-induced NO production in RAW264.7 Cells. Bull Korean Chem Soc. 2011; 32: 4059-62.

30. Park S, Lee DK, Yang CH. Inhibition of fos-jun-DNA complex formation by dihydroguaiaretic acid and in vitro cytotoxic effects on cancer cells. Cancer Lett. 1998; 127: 23-28.

31. Sharifi-Rad J, Sureda A, Tenore GC, Daglia M, Sharifi-Rad M, Valussi M, et al. Biological activities of essential oils: from plant chemoecology to traditional healing systems. Molecules. 2017; 22: 1-55.

32. Lu X, Yang L, Chen J, et al. The action and mechanism of myrislignan on A549 cells in vitro and in vivo. J Nat Med. 2017; 71: 76-85.

33. Wicaksono BD, Tangkearung E, Sandra F. Brucea javanica leaf extract induced apoptosis in human oral squamous cell carcinoma (HSC2) cells by attenuation of mitochondrial membrane permeability. Indones Biomed J. 2015; 7: 107-10.

34. Rizal MI, Sandra F. Brucea javanica leaf extract activates caspase-9 and caspase-3 of mitochondrial apoptotic pathway in human oral squamous cell carcinoma. Indones Biomed J. 2016; 8: 43-8.

35. Yuan J. Caspases in apoptosis and beyond. Oncogene. 2008; 27: 6194-206. 